\title{
Clientelism and conceptual stretching: differentiating among concepts and among analytical levels
}

forthcoming in Theory and Society

Tina Hilgers

Department of Political Science

Concordia University

1455 de Maisonneuve Blvd. West

Montreal, Quebec, Canada

H3G $1 M 8$

Tel: 1-514-848-2424 ext. 2137

Fax: 1-514-848-4072

e-mail: bettinahilgers@gmail.com

The concept of clientelism has lost descriptive power. It has become indistinguishable from neighboring concepts and is applied across analytical levels. Using Gerring's (1999) characterization of a 'good' concept, I establish the core attributes of clientelism, which, in addition to being an interest-maximizing exchange, involves longevity, diffuseness, face-to-face contact, and inequality. Using secondary sources and fieldwork data, I differentiate clientelism from concepts such as vote-buying and corruption and determine its analytical position at the microsociological level. I argue that labeling sociopolitical systems as clientelistic is awkward since, operating at a higher analytical level, they have characteristics beyond microsociological clientelism and they affect the political nature of the clientelism they contain. I conclude that differentiating clientelism confining it to the microsociological level will aid theory-building.

Clientelism, vote-buying, political machines, neo-patrimonialism, conceptual stretching, concept building 
The vast literature on clientelism is marked by the struggle to explain the difference between the formal, impersonal and universally applicable channels and institutions that are identified with democracy in theory - and ostensibly implanted in practice - and the more personalized exchanges (ranging from benign to sinister) that occur in real politics, all efforts to eliminate them to the contrary. Searching for the causes and effects of these exchanges is crucial to understanding political realities and to improving the development and practical application of theoretical ideals. However, the concept misformation (to cite Sartori 1970) or - more aptly, in this case, - deformation that has occurred in the evolution of research into clientelism does not aid the cause.

Contemporary research on clientelism has its roots in 1960s and 1970s sociological and anthropological studies of traditional societies. Originally considered as an intricate personal relationship involving norms of reciprocity between two individuals engaged in the exchange of goods and services, clientelism has gradually come to be applied to a broad variety of political exchanges. Social scientists began to observe behavior like that described by the traditional clientelism in activities linking agricultural villages to central markets; representing villages and urban slums in central politics; and facilitating the exchange of information and resources, negotiation of policy, and filling of positions in political and governmental institutions. The desire to describe these phenomena and to compare their significance across historical periods and geographical as well as hierarchical space caused a broadening use of the term clientelism.

However, discarding or altering characteristics defining the traditional clientelism has voided the concept of descriptive power in a result opposed to the desired effect. Despite calls for specification (Graziano 1976, 1983), the problem persists. Some researchers continue to use clientelism to indicate diffuse, long-term interactions involving shows of personal concern and liking between the parties involved; others label it an interest-maximizing exchange of goods and services and apply it to incidents ranging from vote-buying to pork-barreling; some use it to label organizations and political systems; and yet others use it with little explanation of what it is intended to convey. Clientelism is no longer clearly differentiated from neighboring terms, making it a poor concept difficult to operationalize and to use for theory-building (see Gerring 1999).

The goal of this article is to identify the core attributes of clientelism and the analytical level at which it operates. In addition to being an exchange in which individuals maximize their interests, clientelism involves longevity, diffuseness, face-to-face contact, and inequality. That is, it is a lasting personal relationship between individuals of unequal sociopolitical status.

Establishing these characteristics facilitates differentiation from concepts such as vote-buying and corruption and determines clientelism's analytical position at the microsociological level. Clientelism can be contained in meso and macrosociological organizations and structures, but the latter are more complex than clientelism. In fact, the internal form of clientelism varies partially with external, macrosociological structures - being more democratic or authoritarian depending on the levels of competition and participation in the system - making the labeling of a system as clientelistic per se awkward.

To be sure, analytical categories and levels are not airtight. Empirical cases will often cross the line between categories and levels, combining characteristics (Smelser 1997). The separation between theoretical abstraction and empirical complexity does not, however, render 
the exercise of generalization unproductive. It provides a heuristic starting point from which to undertake empirical research and to organize comparative study.

\section{Some guidelines for concept creation}

Sartori's (1970) and Collier and Mahon's (1993) are among the most widely cited analyses of concept building in political science. According to Sartori's 'classical' approach, a primary, general category should be used for the higher level of abstraction and a series of secondary categories that include all of the primary category's characteristics and add further elements that are present in particular cases. Collier and Mahon describe two further methods of categorization that allow for more slack in concept building and application. Radial categories are characterized by a central, primary category, representing a Weberian ideal type, and a number of secondary categories that branch out from the primary definition. The secondary categories share one or some of the primary characteristics, but divide the rest, so that each branch may have relatively little in common with the others. In family resemblance categories, defining attributes do not have clear boundaries: the category describes a series of cases quite well although there may not be any one characteristic that is shared by all members.

Despite their popularity, these are only three among innumerable positions on concept formation in language, philosophy, history and the social sciences. The variation of possibilities is such that one might give up, with the justification that all concepts depend on their context. However, Gerring (1999) argues that this challenge should motivate analysts neither to surrender nor to attempt to follow a strictly rule-based approach, but to find an acceptable balance among the desirable aspects of a good concept. A concept should be catchy, intuitively clear, and hold to the established characteristics with which it is associated. It should be expressed according to a core characteristic, on which secondary characteristics depend, and be easily identifiable with its empirical manifestations. At the same time, the concept must be clearly differentiated from those that surround it, have enough depth of non-essential characteristics to make it richly descriptive, and be of some use for theory building.

The concept of clientelism fails on depth and differentiation in much of the literature, as we will see in the next section, making it difficult to use for theory building.

\section{Stretching clientelism}

Reciprocal, exchange-based relationships have existed in traditional and modern sociopolitical settings. Based on kinship, community, and/or access to resources, they have ensured survival in agrarian subsistence and primitive trading societies, social integration and mobility where political centers are geographically or structurally removed from the periphery, lubrication of inefficient or ineffective bureaucratic agencies, passing of knowledge and positions, and so on. These relationships are not necessarily efficient or effective at all times but, for reasons ranging from tradition through socioeconomic structure to relative ease of application, often exist where rational, impersonal, bureaucratic structures would seem more appropriate. Despite the different settings in which these exchanges take place and the varying content of the relationships, they have generally been labeled or defined as clientelism.

In the social sciences, the study of clientelism gained popularity during the development era, as sociologists and anthropologists studied traditional societies, analyzing kinship, community, and landlord-peasant relationships. Links between peasants and local chiefs or landlords were described as patron-client links, with the terms patronage and clientelism being 
relatively interchangeable. From these studies arose a commonly accepted definition of clientelism that would form the base for future research. According to this definition, clientelism involves a long-term relationship between two people of unequal status who have relatively regular personal interactions. They exchange goods and services whose value is objectively noncomparable - the higher status person having access to goods and services of a higher market value than the lower status person who can generally offer only political support or labour - but whose importance to the receiving party makes the interaction worthwhile. The relationship covers a broad range of goods and services that are generally not reciprocated immediately, making it difficult to know whether the parties are even and adding to the longevity of the bond. Though the terms of the agreement are not rooted in law, both parties understand their obligation to reciprocate and that disappointing the other's expectations may lead to a breaking off of the relationship (see, for example, Landé 1977; Scott 1977; Mintz and Wolf 1977; Eisenstadt and Roniger 1984).

In essence, peasants in need of resources (land, seeds, tools and credit, technical or legal advice and dispute mediation) or protection from vagabonds sought out relationships with powerful figures within their own community or the landed elite, in the hope that these individuals would become personal benefactors. In return for access to needed resources, the peasant provided labour, gifts, deference, shows of affection, and political support to the patron, enhancing the latter's status. Such relationships were built on mutual trust that the other party would fulfill his obligations and generally endured over long periods of time covering any number and type of exchange.

A much-debated aspect of such relationships is their voluntarism. Voluntarism constitutes - both in fact and in definition - a significant internal contradiction of patron-client relationships (Roniger 1990). Since such interactions are not ruled by law, they cannot be legally enforced. Clients are, theoretically, free to choose their patrons and free to exit the relationship should it not be to their satisfaction (Gouldner 1977). At the same time, many studies of patron-client links have exposed their exploitative nature. Some of these emanate from the structuralist camps, with researchers arguing that a clientelistic relationship may well appear to the individual client to fulfill his need, but clientelism as such is a mechanism of social control that serves to undermine horizontal class relations and allow the elite to maintain its grasp on power (Singelmann 1981). Others come from diverse research schools and point to the fact that seemingly voluntary clientelistic relationships have often been backed by the threat of repression or withdrawal of resources should the clients fail to comply with the patron's wishes (Auyero 1999; Fox 1994). The degree of voluntarism is, thus, probably related directly to the size of the client's resource base and/or access to alternative patrons - that is, to his relative power vis-à-vis the patron.

A common element among social scientists studying clientelism was the tendency to see this as a traditional relationship that would disappear as society modernized and professionalized state agencies began to redistribute resources and ensure security based on impersonal regulations, eliminating the need for private arrangements with patrons. It was thus contrary to all expectations that central administrative structures and markets in fact connected with traditional sectors in the countryside through an interface mirroring clientelism. Local strongmen, businessmen and professionals now traded their expertise in the rules of the external world with local clients, while party machines developed to reach voters in the countryside and in urban slums and savvy patrons acquired official positions with access to state resources. Analysts found reciprocal, exchange-based relationships in various instances at all levels of 
sociopolitical organization, and began to use the often-interchangeable terms clientelism, patronage, and patron-clientelism to describe them all.

Some of these terminological reapplications are accompanied by detailed specifications of differences and by additions of adjectives to identify phenomena more or less closely related to the traditional definition of clientelism. For example, Cornelius (1977) discusses the increase in autonomy and decrease in affectivity found in clientelistic relationships in Mexican urban slums versus the countryside, as urban clients had a wider choice of patrons whose behavior was somewhat more policed by the hegemonic party. Weingrod (1977) carefully distinguishes between the intricate social relationships linking patrons and clients in Sardinian villages prior to the fascist era, and the less personal, more short-term exchanges centered on campaign politics that accompanied the rise of the mass political party and greater state presence in society. Fox (1994) notes a shift from an "authoritarian clientelism" that relied on repression to a "semiclientelism" that could only use the threat of benefit removal to gain client cooperation, as the Mexican Institutional Revolutionary Party (PRI) gradually lost hegemonic power. And Gay's (2006) "thin clientelism" describes the firmly anchored, but indirect, exchange logic that ruled the reaction of voters in a Brazilian slum to the state government's universally implemented infrastructure programs.

Other studies broadening the use of the term clientelism are driven by the desire for parsimony and have stripped the traditional definition of a series of characteristics to make it broadly applicable. Thus, Stokes (2007) labels clientelism "the proffering of material goods in return for electoral support, where the criterion of distribution that the patron uses is simply: did you (will you) support me?". Piattoni (2001) wishes to modernize clientelism by defining it as a rational, interest maximizing exchange of votes or other forms of political support for benefits. Kitschelt and Wilkinson (2007) call it a "transaction, the direct exchange of a citizen's vote in return for direct payments or continuing access to employment, goods, and services".

Both approaches adhere to rules of concept formation, though they do so in different manners. The first set of researchers uses a traditional definition of clientelism as a central category, adding additional characteristics and removing others in creating radial categories that describe specific cases. This method is popular among ethnographers - researchers likely to search out detailed variations among particular instances of clientelism. The second group has more affinity with Sartori's classical method, stripping clientelism of all but one, essential defining element in order to extend it to the level of a primary category applicable to a wide variety of cases. Individual cases that exhibit other characteristics in addition to the fundamental element exist at a secondary level of lower abstraction. Researchers using this method are usually interested in comparing numerous cases that fall broadly into the category of clientelism. Both approaches, and the goals for which they are used, have their merits.

However, numerous case studies of clientelism neither employ an identifiable strategy for concept-building nor seek to strike a balance among the desirable elements for creating a good concept. These are generally highly interesting studies of informal political exchanges that have significant impact on the formally established rules and channels of democratic politics. They tend to describe exchanges that include votes, money and/or public resources and benefit at least one of the parties to the bargain in a manner described as undermining formal democratic processes. Candidates for public election buy votes; certain electoral districts benefit unfairly from public works programs based on their representatives' bargaining power in various governmental fora; citizens bribe officials; governing parties bribe members of the opposition; friends and supporters receive jobs that they do not merit; citizens - individually or in groups - 
and their patrons build lasting relationships in which they exchange all manner of goods and services; dissidents are economically or physically threatened; and some political parties or governments engage in all of these practices. All of this is described as clientelism. Despite the intrinsic value of these research contributions, their indiscriminate use of the term clientelism has voided the concept of descriptive power and makes it difficult to compare a case described in one study to that in another.

One might defend the lumping together of vote-buying, pork-barreling, bribery, corruption, clientelism, patronage, friendship, violence and machine politics under the general heading of clientelism as fair due to family resemblance. That is, these phenomena resemble each other enough to fall into the same category, although none perfectly fits the categorical definition (Collier and Mahon 1993). The expected duration, diffuseness, participants and degree of contact between them, goods and/or services involved and the analytical level of the exchanges may differ. But, because they all involve a more or less sinister misappropriation of public goods and misuse of representation that should be democratic, they are of one family.

This position might be more appropriate if the family were corruption than if it is clientelism, since the former better denominates the common 'aura' (since family resemblance denies the necessity of a shared characteristic) than the latter. Regardless, other problems complicate the argument. The definition of corruption is as, if not more, fraught as that of clientelism (Philp 1997). Machine politics occurs at a higher level of analysis than individual bargains such as vote-buying and friendship. Not least, clientelism can have certain democratic aspects that would make it rather a black sheep (Hilgers 2009).

In sum, a good deal of the contemporary literature does not engage with many of the elements necessary to creating a good concept of clientelism (see Gerring 1999). Though clientelism, as it is often used, appears intuitively familiar and briefly definable (as an unfair and anti-democratic political exchange) it is neither deep nor externally differentiated. It does not have enough specific properties to render it useful for conveying much with the simple use of its name (depth), nor is it well-bounded enough to clearly differentiate it from surrounding concepts. Clientelism has become so blurred as to be haphazardly interchangeable with something as brief and operationally straightforward as a candidate paying a citizen a certain amount of cash on election day for his vote and something as durable and complex as the Christian Democratic Party's political control in southern Italy. As a result, it is both difficult to operationalize clientelism and to use it for theory-building.

\section{Putting clientelism in its place - definitionally and analytically}

To be sure, the essential characteristic of clientelism is the interest-maximizing exchange of resources for political support - the characteristic that is identified by researchers, such as Piattoni (2001), influenced by rational choice and aiming for broad comparison. However, there are several accompanying, defining elements that add depth to this definition and that allow its differentiation from neighboring concepts: longevity, diffuseness, face-to-face contact and status inequality. Clientelism is not only an exchange, but also a personal relationship. It is not one transaction, fixed in time, but a series of interactions that play out over time and involve a range of goods and services traded between two parties who develop trust in each other's commitment. It is not an egalitarian bargain, but one that hinges on power and the lack thereof, as two persons of unequal status negotiate the rules of engagement.

That clientelism is a personal relationship is significant in that it allows for differentiation from other types of exchanges. This, in turn, circumscribes the analytical level at which the 
concept has descriptive power. The clientelistic relationship functions at the lowest analytical level of individual political actors. At the meso and macro levels, organizations and states or systems may contain clientelistic relationships, but they should not be described as clientelistic per se.

At the same time, although the type of organization and/or system in which a clientelistic relationship is found affects its dynamics, the essential characteristics of the relationship remain constant. System and organization, as well as the patron's role within these, bear on the relative degrees of power of the parties involved in clientelism. Competition among patrons for clients in selection or election for public or private office or in efforts to increase private socioeconomic standing - gives clients a choice among patrons and, therefore, greater bargaining power. Where democratic processes exist, would-be clients may also have opportunities to access resources through publicly regulated procedures, increasing the price of their loyalty to a patron. However, where patrons are sparse and/or form a hermetic class and few or no alternatives for accessing resources exist, clients have less power to negotiate. ${ }^{1}$ Notwithstanding its democratic or authoritarian, electoral or administrative, public or private arena, the defining characteristics of clientelism do not change. In all cases, the relationship involves a series of face-to-face exchanges in which the person of greater status gains power through elements such as the vote, favors owed, or loyalty, and the person of lesser status gains special treatment or resources that are not readily available to everyone in the same, or similar, positions. In sum, 1) the concept of clientelism is analytically confined to the microsociological domain, and 2) the power differential in any one clientelistic relationship is affected by the systems, structures, and institutions in which it is embedded, but 3) the nature of these higher levels of analysis does not alter the essential characteristics of clientelism. This constant is what allows us to compare across time and space. It is what gives the concept descriptive power.

\section{Relationship level}

At the microsociological level of analysis, individuals interact based on expectations of others' conduct. For Weber (1978), social relationships are constituted of actors behaving toward and with each other. He categorizes social action as carried out rationally to meet goals that are subjectively useful (instrumental) or valued for their own sake, or as carried out without calculation for emotional (affectual) or traditional reasons. Homans (1958) adds that all social behaviour is rooted in an exchange of goods, information, affection, approval, and/or prestige that either reaches equilibrium, as the individuals adjust the amount they give according to the perceived costs and benefits, or lapses, if one or both parties view it as too costly. This is not to say that individual action and interaction occurs in a vacuum. The microsociological is intimately interlinked with the meso and macrosociological levels (Giddens 1986); thus, we see a continuum of clientelism that includes repressive and participatory variations depending on systemic characteristics. Among the political relationships broadly labeled as clientelism in the literature, we find a variety of individual exchange-based relationships. Some are easily identifiable as instrumentally rational and short-lived, while others cross the lines among instrumental, value, emotional and traditional causes.

The clientelistic exchange relationship is well-described by the landlord-peasant bond explained above, as well as by fictive kinship, such as the customary Latin American

\footnotetext{
${ }^{1}$ See Scott (1977: 125-26) for a discussion of the relative degrees of power of patron and client in traditional agrarian settings.
} 
compadrazgo, which involves the choosing of a person with access to needed resources as godmother or father to one's child, in view of creating a long-term bond (Mintz and Wolf 1977). Compadres are chosen strategically, but the bond is one aspect of the traditional relationship between individuals from different socioeconomic classes that calls upon the better-off to bestow some measure of goodwill upon those of lower status, simultaneously allowing them to enhance their prestige by gathering a loyal following.

Ties between local economic or political strongmen and citizens may also be clientelistic. Such relationships sometimes involve the channeling of public goods through private connections, when a public official or elected politician gives his clients preferential access to state resources. For example, a municipal mayor in Mexico City uses a political operator to organize senior citizens' groups. The citizens attend the groups as a welcome change from their daily routines and they develop a relationship with the operator. They extol the operator's virtues - she is a good organizer, an important and good person - and some are generally to be found accompanying her while she goes about her business in the neighborhood. In the group meetings, the citizens receive information about the mayor's party and are asked to participate in events held by the party; if they participate faithfully, they receive food baskets from the municipality. The mayor and the operator use public goods to gather followers and use the groups to build their political capital, but they also feel some degree of responsibility for the welfare of "their" people (evidence from author's fieldwork in Mexico City in 2004). In other cases, the goods distributed are private, emanating from the patron's personal wealth or technical expertise. This occurs with India's naya netas, new local leaders with better education and contacts to the outside world than other villagers, who gather loyal followers based on their political and economic knowledge (Krishna 2007).

Clientelism should be seen as a continuum that may involve repression or relatively participatory exchanges between patrons and clients. The position of a particular relationship on the continuum depends on the sociopolitical context in which it occurs. For example, landlordpeasant relationships in traditional societies or where state penetration of the countryside is limited sometimes include debt-bondage (Singelmann 1981), while community leaders in more competitive polities are held accountable for their actions by members (Gay 1999) and such relationships may even result in clients learning certain participatory skills (Hilgers 2008).

Friendship is a personal exchange relationship that is akin to clientelism but not part of the clientelistic continuum due to the relative socio-economic or political status of both members to the bargain. In ancient Roman society, patrons - members of the wealthy, political elite entered exchange-based relationships both with humble men of much lower status and with junior members of the elite. Patrons would not humiliate other members of the elite by referring to them as clients, preferring to call them friends and receiving them much more graciously than clients, although similar unwritten rules of obligation and deference applied (Gelzer 1969; Saller 1982). Such friendship is also pervasive in the contemporary Chilean middle classes, where many people have friends in the civil service and continually exchange favours with them (Lomnitz 1988). The friends are members of the same class, but are in positions giving them access to different types of goods and services that can be traded without having to go through complicated official channels. Each friend thus has access to resources the other needs, while the patron-client relationship is marked by a one-way flow of resources from patron to client. Save for loyalty, the client has little to offer that the patron values.

Clientelism, compadrazgo and friendship are instrumentally rational, but they also contain elements of emotion, tradition and value. Friends are bound to feel a certain degree of 
affection for each other. In rarer cases this may be true for compadres or patrons and clients, though here affection - and traditional shows of respect and deference - are usually performed rather than genuine (Auyero 1999), masking profound feelings of mistrust and dislike between those who have power and those who do not (Scott 1985). The longevity, diffuseness and faceto-face contact that mark clientelism and its related relationships - and the inequality that characterizes clientelism - set them apart from other exchanges.

Patronage is closely linked to clientelism, although its key defining characteristic - the discretionary distribution of public office - is not necessarily shared by clientelism. Patronage entails the distribution of public sector jobs by a candidate or party to loyal supporters who have helped to generate votes. The votes in question are often produced through clientelism (Remmer 2007). Thus, groups can be involved in exchange-based relationships through patronage: a patron develops individual links with a number of individuals, who are his clients. The patron also fosters ties with individuals of higher political status who confer favors upon him in return for the assurance that his followers will politically support the party in question. The patron thus becomes a broker or mediator (Weingrod 1977). Significantly, all of the relationships involved are individual: each client bargains with the patron and the patron negotiates with his contact in the party. I will further discuss the institutionalization of such relationships below.

Although patronage and clientelism often appear together, the terms are not interchangeable. McCourt (2000) groups them with kinship and labels them a "moneyless form of corruption" that is present in public administrations the world over where various personal considerations undermine merit-based appointments. He suggests that such corruption can be successfully combated with institutions that clearly identify merit and regulate the filling of positions according to this definition. Notwithstanding the documented, conflictive coexistence of values supporting rational-legal institutions with values demanding traditional loyalties (see Lomnitz 1988 for the Chilean and Mexican cases), patching over the differences among the relationships identified does no favors to the search for mechanisms suitable for the development of professional bureaucracies. Institutional responses should likely emphasize particular characteristics depending on the type of exchange, tradition or corruption - based on family responsibilities, on infrastructural resource scarcity, on lack of judicial independence, etc. - that they are intended to address.

Corruption is frequently equated with the relationships already defined, but should also remain a separate category. ${ }^{2}$ First, corruption is not necessarily exchange-based. Rigging elections and using public money to finance an incumbent's campaign are examples of corruption, but do not involve reciprocity between two parties. Also, corruption, being "the violation of norms based on a distinction between what is public and what is private" (Hutchcroft 1997), clearly involves public office and/or public resources, which is not always the case for exchange-based political relationships. Finally, several seminal works on corruption highlight the importance of attitudes in identifying what is or is not corrupt. The line between public and private is crossed when a public official does a favor in return for a pay-off from the recipient of the favor. However, whether and how corrupt the act is depends on the opinions - and therefore the political norms - of political elites or public officials and the public, who make their judgments based on the position of the individuals or groups involved, the nature of the favour,

\footnotetext{
${ }^{2}$ Work on corruption has been faced with many problems similar to those rendering the definition of clientelism difficult. A plethora of definitions exist and there is little agreement on what constitutes corruption, either in theory or in practice (Philp 1997).
} 
and the amount and type of pay-off (Peters and Welch 1978). The norms in question are context dependent: in some cultural and institutional settings the distinction between public and private is viewed differently than in others (Philp 1997).

In settings marked by long-term resource shortages, participants perceive the practice of clientelism as a necessary and normal activity, not as a violation of politico-institutional norms. The practice is everyday politics engaged in regularly by citizens at large, while the term is a sensitive topic - the two are not mutually exclusive. For instance, Mexicans' lives are marked by reciprocal exchanges between individuals of unequal status, yet these exchanges are rarely considered in terms of clientelism. At the same time, educated people in general and politicians and officials in particular associate clientelism with the authoritarian era and its ruling party's undemocratic behavior. The exchanges are ubiquitous and many politicians will discuss them freely as a normal part of politics, but the word is seen as negative and no one wants to be perceived as clientelistic (author's fieldwork, Mexico City 2004).

In other cases, analysts misuse the terms. Thus, Avritzer (2006) labels as clientelistic the Brazilian ruling party's use of a slush fund to pay for its electoral campaigns, a case that would be more appropriately labeled as corruption. Critics are also quick to signal as corrupt the Brazilian president's appointment of thousands of public officials. Many of the important positions will inevitably go to trusted persons, but this patronage is the president's legal right. Similarly, the Canadian prime minister has the traditional privilege of appointing members to the senate and tends to grant these positions to loyal party supporters. These are patronage positions, to be sure, and there is much debate about making the senate an elected body in order to render the system more representative, but whether the existing system constitutes corruption is a matter of interpretation. Thus, although certain instances of clientelism or patronage may be perceived as corrupt, it is best to maintain a definitional divide among the concepts and to evaluate coincidence between them on a case-by-case basis.

Also unlike clientelism and friendship, vote-buying is a one-shot, direct exchange, in which the participants have no particular characteristics other than that the recipient is a voter (Schaffer 2007). An individual citizen is given money, goods, or services shortly (hours or days) prior to an election in exchange for his or her vote. In the case of poor voters, this can involve providing transportation, entertainment, and/or a meal on an election day to individuals who would otherwise be working, and instructing these voters on how to mark their ballots. For instance, local Mexico City politicians hire buses to transport citizens to the polls (an operation known as acarreo), doing their best to ensure that the favor is returned (author's fieldwork, Mexico City 2004). Schaffer (2004) lists the dollar amounts paid for votes in some East Asian elections, ranging from the equivalent of $\$ 0.60$ US during community elections in a poor Manila neighborhood in 2002, to \$60 US for middle class votes in a 2003 Taiwanese county by-election. Such one-shot bargaining is underwritten by a reciprocal, exchange-based logic, but is confined to a brief and impersonal contract that differs markedly from the diffuse relationship of clientelism. Vote-buying is more clearly confined to the Weberian category of instrumental rationality and follows Homans' logic of termination due to excessive cost, since politicians cannot finance a continuous buying of loyalty.

The conceptual differentiation between vote-buying and clientelism is empirically grounded. As Stokes $(2005,2007)$ demonstrates, any such exchange involves a commitment issue. Both patron and client want to be relatively certain that the other party will uphold his end of the bargain. However, when the exchange is one-shot, it is logically preferable for both sides to break the bargain: it makes sense for the voter to accept a gift or a promise thereof, but then 
vote his conscience, and for the candidate to make a promise in exchange for the vote and break the promise upon winning the election. When the link is face-to-face and long-term, on the other hand, the participants become part of a social network within which they and their habits and behaviors are known. For Stokes, this results in a "perverse accountability" through which local party operatives are able to monitor voter behavior despite the secret ballot. The monitoring can, in fact, go both ways, as the voting members of the network also exchange information regarding the reliability of candidates and are able to sanction those who break their promises or make overly onerous demands in subsequent exchange rounds (Hilgers 2009). ${ }^{3}$ The longevity of the clientelistic relationship facilitates accountability, however perverse, and provides much higher incentives for compliance than vote-buying. Nonetheless, there may be some overlap between the two, where the buying of votes is limited to electoral periods but occurs over several elections and between known players - familiar party candidates or brokers and a community with identifiable members. While such exchanges resemble vote-buying more than clientelism since they are not diffuse and not necessarily face-to-face or between people of unequal status, they do include the repetition that defines clientelism.

Despite their differences, clientelism and vote-buying are often used interchangeably. Wang and Kurzman (2007) argue that clientelism is not as effective as generally assumed, since clients often do not comply with their patrons' political directives. However, the literature they review is one that assumes durable and diffuse clientelistic relationships, while the case they test is one in which political operators bought votes on the eve of the 1993 Taiwanese election. It may well be that clientelism often fails to produce the desired votes, but a study of vote-buying cannot test this hypothesis. Gay's (1999) insightful work on politics in a Brazilian favela portrays the relationship between a community leader and a series of candidates for political office as clientelistic. Yet, the deals struck between the two parties were confined to the period immediately preceding an election: the politician in question saw to the paving of the neighborhood's streets or provided funding for a local project and in return the president instructed his community to vote for the politician. There were no long-term arrangements with a single politician in which it was understood that electoral support would be forthcoming for all of the favors done by the politician over the interim period. Instead, every election was negotiated and support went to the highest bidder. To be sure, the relationship between the community members and their president may have been clientelistic, but this is not the crux of Gay's argument.

Pork-barreling is also often conflated with clientelism. Here, politicians act according to electoral motivations rather than for the greater good by promoting distributive policies that will benefit their own districts, but whose costs are carried by the entire electorate (Ricci 2003).

Regardless of which politician they support, everyone in the receiving constituency benefits from the policy, making the relationship neither personal nor dependent on the recipient's reciprocal actions and, therefore, not clientelistic. Of course, if the politician is not reelected, she will not continue to pass goodies the way of her district - though her successor may - but the same is true of any type of targeted program, even those that are ideologically motivated. While porkbarreling is often present in conjunction with clientelism, the two are not the same.

\footnotetext{
${ }^{3}$ See also the new economic sociology discussions of informal bargains in the absence of legally enforceable contracts in the informal economy, Portes and Haller 2005; Centeno and Portes 2006; Cross and Peña 2006.
} 
In a unique field experiment conducted during Benin's 2001 election, Wantchekon (2003) worked with the presidential candidates' campaign managers to present some villages with public policy platforms and others with what he calls clientelist platforms. Both platforms included health, education and infrastructure issues, but the one labeled as clientelistic presented the issues as local projects, while the policy platform described them as national ones. The most immediate problem here is that a political platform necessarily lays out some type of program for the electorate at large; this is not an exchange relationship that evolves over time and a series of transactions. Of course voters must support the candidate presenting the platform in order to benefit from his program, but this is also the case with ideological programs. The platforms presented by Wantchekon would be more appropriately labeled pork, than clientelist. Wantchekon found that the pork platform was most effective in areas controlled by regional parties and he hypothesizes that this may have been because national-level opposition parties are more credible on public policy. However, in an argument parallel to Wantchekon's hypothesis, this could be where clientelism actually does play a role, since regional party politicians are more likely to have developed durable relationships in their local strongholds with clients that are receptive to the promises of pork as part and parcel of a preexisting exchange logic.

In sum, clientelism operates as a personal relationship at the microsociological level, along with a series of other phenomena that are either related to it or that often occur in conjunction with it, and whose definitional distinction is important for identifying the forces at work. Clientelistic relationships are often found in social and political organizations, but exist here alongside other types of links, not all of which are personal, exchanges, or relationships.

\section{Organizational level}

At the mesosociological level, we find organizations. According to Weber (1978), these are bodies with restricted access constituted of social relationships and functioning according to rules implemented by an executive. While this is a straightforward definition, it refers to relatively complex entities ranging from compact units with few members to large groups. Important bodies of literature in the social and natural sciences as well as in the humanities study organizations of all types and sizes - the types of relationships they contain, their effects on members and on surrounding societies and environments (and the reverse) and so on. Business and management studies include extensive theories on the causes and consequences of organizational behavior and interaction, with an important subfield on informal group cultures that are said to orient organizational action as much as formal rules (Schein 2004).

Notwithstanding the conceptual inaccuracy of ascribing an interpersonal relationship to an entity, it would be difficult, given the complexity of 'organization', to find an organization that is strictly clientelistic. To be sure, there exist organizations whose central social relationships are clientelistic, but even these either begin with other functions or come to contain other relationships and have other aims almost as soon as they come into existence. For example, a political operator I met in Mexico City in 2004 was contacted by a group of homeowners for help with applying for a government subsidy to renovate their building, whose structure had been affected by an earthquake. He agreed to work for them if they would regularly meet with him to hear his political teachings and attend events organized by his party. As much as the relationship between the individual group members and the operator was clientelistic, the organization had two other important characteristics: the members had already banded together in order to access funding before contacting the operator, and their interaction with him taught them a set of organizational and political skills they did not previously have and could now call upon in other 
situations. In another example, the Frente Popular Francisco Villa (Francisco Villa Popular Front, FPFV) is notorious in Mexico City for its clientelistic strategies. FPFV leaders exchange political support for help in accessing social housing credits with the urban poor and use their followers as leverage in negotiations for public sector jobs, political candidacies, and public resources with the Federal District government. Yet, the organization also has an independent political purpose that often leads it to publicly clash with the government, and it includes a number of communities - squatters and formally established - with all the ins and outs of people living together in close quarters and having to organize themselves to access electricity, potable water, and other public goods and services (author's fieldwork, Mexico City 2004). Both the small and the large organization contain clientelistic relationships, but are more complex in their internal workings and their external effects than what is conveyed by the clientelistic label.

Within these organizations, we also find another empirical reason to conceptually limit the patron-client relationship to one between two individuals: rewards are based on individual compliance. Although an organization may receive what appear to be collective goods from a party, candidate, or government official when the patron responsible for the members of the organization delivers their votes, access to the goods is carefully divided among clients based on individual diligence in fulfilling the bargain. Thus, FPFV patrons carefully record client participation in all manner of political and community events and, when the organization is awarded a social housing project by the government, its most assiduous clients receive the choicest apartments. Returning to Susan Stokes' (2005) logic, incentives must be selective in order for clientelism not to be undermined by free-rider problems.

There is, thus, a group element in clientelistic politics when an organization's strategies for goal attainment involve building patron-client relationships and patrons use their clientelistic following to make bargains at higher echelons of the political hierarchy. Researchers often talk of such patrons as brokers - people who have organizational and leadership skills but lack access to distributable resources and therefore use their abilities to act as middlemen between clients and higher levels of power (see Scott 1977). While clientelism remains a personal relationship that is viable because patrons and clients make individually supervisable bargains based on selective incentives, the relationships and the parties to them are socially embedded, linking together in various ways to form networks and pyramids. ${ }^{4}$

Much as the FPFV and other such organizations, political machines are also more complex than what is allowed by the term clientelism, despite the general tendency to use it and machine politics interchangeably. Mills Ivins' (1887) discussion of several United States District Assemblies - including the infamous Tammany Hall of New York - describes a political machine as an organization with highly centralized power that engages in corruption, violence, patronage, the sale of public office, clientelism and bribery, that gains control of newspapers and fosters links - or even control of - the police and the judiciary. Chubb (1982) also provides an excellent study of a political machine, in her work on the Italian Christian Democratic Party's chaotic rule in Southern Italy and its links with the urban poor, the middle classes, business and the mafia. Although the machine was characterized by the gamut of characteristics listed above and is clearly a higher-level category than individual exchange relationships, Chubb subsumes all of its activities under the general heading of clientelism. More recently, Stokes (2005), in an article resulting from her extensive research into exchange-based political relationships in Argentine

\footnotetext{
${ }^{4}$ For discussions of the social embeddedness of clientelism and other informal contracts, see
} Scott 1977, Granovetter 1985, Portes and Haller 2005. 
politics, employs the terms machine politics, clientelism, and vote-buying as relatively synonymous, missing an opportunity for using her evidence to illustrate the differences among them.

At the mesosociological level, we also find corporatist organizations. ${ }^{5}$ As discussed above, groups can be linked into exchange-based relationships through brokers. Where links between groups and the state are institutionalized, however, they should be referred to as corporatist. Corporatism is a system of interest intermediation, where a strong democratic or authoritarian state and functionally organized interest groups negotiate policy. In return for guaranteed representation in the policy-making sphere, the groups aid in policy application (Adams 2005). Corporatism and clientelism often appear together, particularly in authoritarian systems where politicians and corporatist leaders foster clienteles in order to increase their personal prestige and to ensure rank-and-file quiescence through the hope of access to discretionally distributed goods and services (Middlebrook 1995). Again, the clientelistic links exist at the individual level and, although they are a prominent feature of some corporatist organizations, the organizations are more complex than these relationships.

\section{State or system level}

At the macrosociological level, we find societies, social systems and the state. These are large social entities that contain a series of groups and organizations and a multitude of individuals, but whose character is more than the sum of its parts (Lehman 1978). The problem of complexity already seen at the mesosociological level thus applies here to an even greater extent: the dynamics of systems and states are not reducible to the relationship that is clientelism. While various socio-political systems contain clientelistic links, the broader character of the system affects the particular dynamics of the clientelistic relationships and the former cannot be reduced to the latter.

To be sure, some social systems are identified by characteristics similar to those exhibited by clientelism. Patrimonial regimes are described as being marked by rulers and officials who regard their offices as private property, act in order to preserve their own benefits, and govern by distributing resources as personal favours to loyal followers (Weber 1978; Sandbrook with Barker 1985). These systems are said to function only as long as enough goods and services flow through personal networks to satisfy the receiving individuals and groups (Eisenstadt 1973). However, the historical sociologists using these descriptions place the systems they discuss in a detailed historical narrative explaining regime origins, internal organizations and hierarchies, center-periphery relations, and so on. They neither use their definition lightly, nor do they apply it interchangeably: patrimonialism contains clientelism, but the latter operates at a lower level of analysis and is only one of the patrimonial regime's characteristics. Sandbrook's (1985) discussion of the political reasons that compound the structural roots of Africa's economic stagnation is revealing in this sense.

According to Sandbrook, Africa is hampered by its colonial past, dependency, poor natural resources, a harsh tropical climate, a largely peasant population, small markets, lack of administrative and technical skill, ethnic and religious conflict and inequity in the international economy. In this context, he argues, the population is not politically active and the public sector

\footnotetext{
${ }^{5}$ Corporatism can be identified at both the mesosociological level, in corporatist organizations, and at the macrosociological level, in a form of organizing state-society relationships. See Smelser $(1995,2)$ regarding the blurring of analytical levels.
} 
is not necessarily loyal, making personalism (a type of patrimonialism) the most effective type of rule. Sandbrook describes personal rule as turning on a strongman - usually the president - who is the center of the state's political life, surrounds himself with loyal followers who may be hired and fired at will, forces respect of his person and image, and creates a system of administrative and economic corruption that can only result in economic decline. To attain and maintain power, the strongman uses a personally loyal armed force, to threaten and enact repression, and clientelism, by establishing links with patrons at regional and local levels, in the bureaucracy, in trade unions and in other organizations. However, as Sandbrook is careful to point out, not all personal regimes are the same and the degree of political competition affects the spread of clientelistic spoils. The more authoritarian the system, the more client acquiescence is forced through repression, while competition ensures that benefits are passed to the masses (Sandbrook 1985: 93-4).

Indeed, clientelism not only occurs in more or less competitive patrimonial systems but also in systems that feature - and function, to some degree, according to - institutionalized regulations. Personal exchanges are not essential to the survival of the sociopolitical regime in neopatrimonial systems, which have extensive administrative structures and laws regulating the bureaucracy as well as the distribution of resources. Nonetheless, personalistic elements persist, with central officials concentrating power, seeking rents, and making little effort to develop the periphery, but gathering support among peripheral groups and easing these groups' access to the administration through clientelistic mechanisms (Eisenstadt 1973; Erdmann and Engel 2006).

According to Bratton and van de Walle (1997), a neopatrimonial regime is one in which bureaucratic institutions function based on personal relationships and where officials use clientelism to ensure political order. Despite this assertion, Bratton and van de Walle do not use the term clientelism to describe neopatrimonialism as a whole. They list personal exchanges, clientelism and corruption as separate elements and explain variations in competition and participation among neopatrimonial regimes, which motivate different degrees of patron responsiveness to clients (Ibid., 62, 68-82).

In a discussion of formal and informal institutions in Egyptian politics, Koehler (2008) also identifies clientelism as only one among several elements important to the make-up of the country's neopatrimonial regime. Describing Egypt's formal institutions, he writes that executive and legislative powers are constitutionally mandated, elections are held regularly and according to electoral laws, and opposition parties are licensed and governed by a parliamentary committee. However, Koehler also explains that these formal mechanisms and a set of informal rules permeate each other. Thus, most legislation emanates from a very powerful executive and is accepted with little discussion by the legislature, the ruling party dominates the committee regulating opposition parties, electoral laws are often rewritten prior to elections, and electoral fraud is common. The regime essentially uses elections to legitimate itself and to co-opt opposition elements. Since legislators have little policy-making power but still have to get elected and voters know it, they are motivated to establish clientelistic relationships with each other. As much as Koehler argues that links between Egyptian politicians and voters are thoroughly clientelistic, he clearly traces this phenomenon to broader institutional causes that are as important to the Egyptian system as clientelism.

In contrast to the examples of contextualized, microsociological clientelism described above, some authors apply the concept at the systemic level. Berman (1974) analyzes African political development using an ideal-typical "clientelistic system" in which neocolonial macrostructural dynamics play out in individual states through clientelistic networks that link 
peripheries to centers, voters to politicians, and citizens to holders of public and private office in hierarchies that culminate in powerful central patrons. He describes the feudal, personalistic character of internal center-periphery relations as shaped by neocolonial pressures from above and clientelistic pressures from below, taking particular pains to explain the import of the latter. While Berman's analysis provided an interesting alternative to mainstream perspectives on African development at the time of publication, it lacks the clarity and impact of similar analyses by Eisenstadt and Sandbrook, who used patrimonialism and neopatrimonialism to explain system-level characteristics and kept clientelism at a lower order. In using clientelism to describe a particular type of political system, Berman has to define it as a relationship of domination, used by the elite to subjugate the masses and maintain the status quo - a definition that does not travel well, since the dynamics of clientelism change with contextual factors (see Cornelius 1977; Fox 1994; Gay 1999). In addition, Berman's discussion of the nexus between neocolonial and clientelistic structures is imprecise, as the feudalism and personalism of internal center-periphery relations appear more clearly caused by macrostructural than by microsociological factors. Patrimonialism and neopatrimonialism, on the other hand, clearly subsume such internal structures - alongside the interpersonal exchange relationships of clientelism.

The problems encountered in Berman's application of clientelism to the system level continue elsewhere. Scheiner (2007) also uses the term "clientelistic system", but applies it to Japanese politics. He argues that institutional and structural factors - including the electoral system, mobilization for early political parties, and land tenure systems - have led politicians of the country's most powerful, and longtime ruling, political party (the Liberal Democratic Party, LDP) to construct clientelistic linkages with voters through groups based on personal support or on economic and industrial sectors (particularly those unable to survive on their own in a competitive market). While Scheiner does contextualize clientelism, his analysis contains several imprecisions: he labels as clientelistic relations between the LDP and economic sectors that would be better described as corporatism, counterposes democracy to what he calls Japan's clientelistic system without clarifying whether this means Japan is undemocratic, and does not define his clientelistic system, leaving the reader unsure as to what a system is meant to be. A broader problem is that we are presented with the "clientelistic systems" of Africa and Japan, that appear to have little in common empirically or theoretically, let alone with - for example Randeraad and Wolffram's (2001) description of the $17^{\text {th }}$ century Dutch Republic as a clientelistic system, in which the prince used clientelism to collect taxes and gather political support.

This is not to say that patrimonialism and neopatrimonialism are superior terms because they are clearly connected with a particular regime type or historical era. Although both tend to be associated with authoritarianism and rational-legal systems with democracy, this is not necessarily the case. Erdmann and Engel (2006) remind us that late nineteenth century Germany was essentially a rational-legal system, though certainly not a democracy. Conversely, a series of contemporary states - such as Nicaragua, Guatemala, Bangladesh, and Ukraine - fall into a "gray zone" that includes democratic and neopatrimonial characteristics (Carothers 2002). Regardless, patrimonialism and neopatrimonialism are specified forms of government and the concepts are intended for the systemic level, whereas clientelism clearly is neither.

Further underscoring the point that systems are only awkwardly labeled as clientelistic is evidence that clientelism and patronage exist in rational-legal systems, the definitional antithesis of personalistic exchanges. A rational-legal system refers to a bureaucracy organized to serve the 
public good, where officials are chosen based on merit and are in office to do a particular job according to established rules and norms (Weber 1978). Sweden may be one of the best cases of a professionalized bureaucracy: the concepts of clientelism and patronage do not appear in any of the major analyses of Swedish politics and some researchers are actually concerned with the opposite problem of too much administrative impersonalism. Nonetheless, there are cases of recruitment based on ideological commitment, class or family ties, although these are explained in terms of efficiency or socialization (Papakostas 2001). In another example, Chicago's Democratic political machine features clientelistic relationships between precinct captains and voters, who exchange all manner of permits, favours and special treatment for political support (Clark 1994). However, the competitive American rational-legal system provides recourse to those unwilling to enter such relationships, an alternative not always available in other political systems. In both Sweden and the United States, the context of political competition, bureaucratic professionalism and judicial independence create a much more democratic clientelism than that found in an authoritarian neopatrimonial system such as Egypt. Given clientelism's dependence on broader systemic factors, its application to systems remains an uneasy fit.

\section{Conclusion}

To recapitulate, making a good concept of clientelism requires differentiating it from neighbouring concepts, which is possible by emphasizing several characteristics beyond the core element of interest-maximizing exchange: longevity, diffuseness, face-to-face contact and inequality. The power relations at play in microsociological clientelistic exchanges vary from repressive to participatory, a continuum that is affected by the degree of competition and participation present in the context in which clientelism occurs. Given this contextual dependence, and the complexity of organizations and systems operating at higher analytical levels, transplanting the micro-term to the meso or macro level is problematic.

In arguing that the micro and macro levels are interlinked, I have referred to Giddens (1986). In the present article, this has been a one-way explanation of structure affecting individual action; an argument made in order to highlight the idea that our concept should be restricted to the lower analytical level. Giddens, of course, sees the interlinkage as clearly bidirectional: individual action also affects the context. In a discussion aimed directly at clientelism, Graziano (1983) also stresses that the microsociological level needs to be linked meaningfully to broader structures and that this should occur through a theory demonstrating the interaction between the characteristics of the relationship and those of the greater society. Graziano emphasizes the manipulation and coercion that are often part of clientelism and calls for research into the links between clientelism, generalized inequality and class analysis. This certainly merits further study - since inequality is one of clientelism's defining characteristics, it follows that the link between clientelism and its politico-economic context is both more subtle and more portentous than what is conveyed by my unadorned statement that the relationship is affected by its context. However, such a quest for theory need not be unidirectional. Interesting work has been done on the constructive value of clientelism in broader organizations and institutions in competitive, but weakly institutionalized, democratic polities (Gay 1999 and 2006; Hilgers 2009; Krishna 2007) evidence that also warrants further consideration. Indeed, should this evidence hold true, it could lead to fascinating policy-based questions: how does clientelism work where democratic institutions fail? What does it do that the formal institutions do not? What can we learn from this? 
Theories of the behavioral-structural interactions between clientelism and its context will also benefit from a clearly differentiated concept of clientelism, which will facilitate the recognition of significant changes across time, as well as across and within political systems. Reviews of the literature on clientelism often refer to the divide between an anthropological clientelism describing traditional relationships in the countryside and a political science one referring to the impersonal and short-term electoral bargains between mass-parties and voters (see, for example, Weingrod 1977). As much as this disciplinary divide exists, using it to explain away multiple definitions of one concept is not helpful, since the empirical foundations of both perspectives exist in the real world and do not confine their effects to disciplinary topics of interest. Clientelism, vote-buying, pork-barreling and other such phenomena at some times appear together and at other times do not. Differentiating among them allows for study of shifts from one to another or of types of co-existence across cases, evidence that may be of significance to broader political changes. 


\section{Acknowledgments}

Previous versions of this paper were presented at the 2009 meetings of the Canadian Political Science Association and of the Société québécoise de science politique. The author would like to thank Judith Adler Hellman, Philip Oxhorn, Julián Durazo Herrmann, Dennis Pilon, Françoise Montambeault, Judith Teichman, two anonymous reviewers, and the editors for their insightful comments on - and discussions surrounding - earlier forms of the paper. Financial support was provided by the Social Sciences and Humanities Research Council of Canada and the Fonds québécois de recherche sur la société et la culture and institutional support by McGill University's Institute for the Study of International Development. 


\section{References}

Adams, Paul S. (2005). Corporatism and Comparative Politics: Is there a new century of corporatism? In Howard J. Wiarda (Ed.), Comparative Politics: History, theory, concepts (pp. 244-269). New York: Taylor \& Francis.

Auyero, Javier. (1999). Performing Evita: A Tale of Two Peronist Women. Journal of Contemporary Ethnography, 27(4), 461-493.

Auyero, Javier, Fernanda Page and Pablo Lapegna. (2008). Patronage Politics and Contentious Collective Action: A Recursive Relationship. Latin American Politics and Society, 51(3), 1-31.

Avritzer, Leonardo. (2006). A crise do governo Lula e a crise do P.T. Reprinted from Jornal do Brasil, June 20, 2006, www.cultiva.org.br/politica.php. Accessed Dec. 5, 2007.

Berman, Bruce J. (1974). Clientelism and neocolonialism: Center-periphery relations and political development in African states. Studies in Comparative International Development, 9(2), 3-25.

Bratton, Michael, and Nicolas van de Walle. (1997). Democratic Experiments in Africa: Regime Transitions in Comparative Perspective. New York: Cambridge University Press.

Burgwal, Gerrit. (1995). Struggle of the Poor: Neighborhood Organization and Clientelist Practice in a Quito Squatter Settlement. Amsterdam: Centre for Latin American Research and Documentation (CEDLA).

Carothers, Thomas. (2002). The End of the Transition Paradigm. Journal of Democracy, 13(1), 5-21.

Centeno, Miguel Angel, and Alejandro Portes. (2006). The Informal Economy in the Shadow of the State. In Jon Shefner and Patricia Fernández-Kelly (Eds), Out of the Shadows: Political Action and the Informal Economy in Latin America (pp. 23-48). University Park: Pennsylvania State University Press.

Chubb, Judith. (1982). Patronage, Power, and Poverty in Southern Italy: A tale of two cities. New York: Cambridge University Press.

Clark, Terry Nichols. (1994). Clientelism, U.S.A.: The Dynamics of Change. In Luis Roniger and Ayse Gunes-Ayata (Eds), Democracy, Clientelism and Civil Society (pp. 121-144). Boulder: Lynne Rienner.

Collier, David, and James E. Mahon. (1993). Conceptual 'Stretching' Revisited: Adapting Categories in Comparative Analysis. American Political Science Review, 87(4), 845855.

Cornelius, Wayne A. (1977). Leaders, Followers, and Official Patrons in Urban Mexico. In Schmidt, Guasti, Landé, and Scott (Eds), Friends, Followers, and Factions: A Reader in Political Clientelism (pp. 337-353). Berkeley: University of California Press.

Cross, John C., and Sergio Peña. (2006). Risk and Regulation in Informal and Illegal Markets. In Jon Shefner and Patricia Fernández-Kelly (Eds), Out of the Shadows: Political Action and the Informal Economy in Latin America (pp. 49-80). University Park: Pennsylvania State University Press.

Durazo Herrmann, Julián. (2007). Enclaves autoritarios post-transición: el caso de México. Paper presented at the XXVII International Congress of the Latin American Studies Association, Montreal, Canada, September 5-8, 2007.

Eisenstadt, S.N. (1973). Traditional Patrimonialism and Modern Neopatrimonialism. London and Beverly Hills: Sage Publications.

Eisenstadt, S.N., and Luis Roniger. (1984). Patrons, clients, and friends. Interpersonal relations and the structure of trust in society. Cambridge: Cambridge University Press.

Erdmann, Gero, and Ulf Engel. (2006). Neopatrimonialism Revisited: Beyond a Catch-All Concept. German Institute of Global and Area Studies, Working Paper No. 16. 
Fox, Jonathan. (1994). The Difficult Transition from Clientelism to Citizenship: Lessons from Mexico. World Politics, 46(2), 151-84.

Gay, Robert. (1999). The Broker and the Thief: A Parable (Reflections on Popular Politics in Brazil. Luso-Brazilian Review, 36(1), 49-70.

Gay, Robert. (2006). The Even More Difficult Transition from Clientelism to Citizenship: Lessons from Brazil. In Patricia Fernández Kelly and Jon Shefner (Eds), Out of the Shadows: Political Action and the Informal Economy in Latin America (pp. 195-217). University Park: Pennsylvania State University.

Gelzer, Matthias. (1969). The Roman Nobility. Oxford: Basil Blackwell.

Gerring, John. (1999). What Makes a Concept Good?: An Integrated Framework for Understanding Concept Formation in the Social Sciences. Polity, 31(3), 357-93.

Giddens, Anthony. (1986). The Constitution of Society: Outline of the Theory of Structuration. Berkeley: University of California Press.

Gouldner, Alvin W. (1977) [1960]. The Norm of Reciprocity: A Preliminary Statement. In Schmidt, Guasti, Landé, and Scott (Eds), Friends, Followers, and Factions: A Reader in Political Clientelism (pp. 28-43). Berkeley: University of California Press.

Granovetter, Mark. (1985). Economic Action and Social Structure: The Problem of Embeddedness. The American Journal of Sociology, 91(3), 481-510.

Graziano, Luigi. (1976). A Conceptual Framework for the Study of Clientelistic Behavior. European Journal of Political Research, 4, 149-74.

Graziano, Luigi. (1983). Introduction. International Political Science Review, 4(4), 425-434.

Hilgers, Tina. (2008). Causes and Consequences of Political Clientelism: Mexico's PRD in Comparative Perspective. Latin American Politics and Society, 50(4), 123-153.

Hilgers, Tina. (2009). Who is Using Whom? Clientelism from the Client's Perspective. Journal of Iberian and Latin American Research, 15(1), 51-76.

Homans, George C. (1958). Social Behavior as Exchange. The American Journal of Sociology, 63(6), 597-606.

Hutchcroft, Paul D. (1997). The Politics of Privilege: Assessing the Impact of Rents, Corruption, and Clientelism on Third World Development. Political Studies, 45(3), 639658.

Kitschelt, Herbert, and Steven J. Wilkinson. (2007). Patrons, Clients, and Policies: Patterns of Democratic Accountability and Political Competition. New York: Cambridge University Press.

Koehler, Kevin. (2008). Authoritarian Elections in Egypt: Formal Institutions and Informal Mechanisms of Rule. Democratization, 15(5), 974-990.

Krishna, Anirudh. (2007). Politics in the Middle: mediating relationships between citizens and the state in rural North India. In Kitschelt and Wilkinson (Eds), Patrons, Clients, and Policies: Patterns of Democratic Accountability and Political Competition (pp. 141158). New York: Cambridge University Press.

Landé, Carl H. (1977). Introduction: The Dyadic Bases of Clientelism. In Schmidt, Guasti, Landé, and Scott (Eds), Friends, Followers, and Factions: A Reader in Political Clientelism (pp. xiii-xxxvii). Berkeley: University of California Press.

Lehman, Edward W. (1978). Sociological Theory and Social Policy. In Amitai Etzioni (Ed.), Policy Research (pp. 7-23). Leiden: Brill.

Lomnitz, Larissa Adler. (1988).“'Informal Exchange Networks in Formal Systems: A Theoretical Model. American Anthropologist, New Series, 90(1), 42-55.

McCourt, Willy. (2000). Public Appointments: from Patronage to Merit. Human Resources in Development Group Working Paper Series Working Paper No. 9, Institute for Development Policy and Management, University of Manchester.

Middlebrook, Kevin J. (1995). The Paradox of Revolution: Labor, the State, and Authoritarianism in Mexico. Baltimore: Johns Hopkins University Press. 
Mills Ivins, William. (1887). Machine Politics and Money in Elections in New York City. New York: Harper \& Brothers.

Mintz, Sidney W., and Eric R. Wolf (1977) [1950]. An Analysis of Ritual Co-Parenthood (Compadrazgo). In Schmidt, Guasti, Landé, and Scott (Eds), Friends, Followers, and Factions: A Reader in Political Clientelism (pp. 1-15). Berkeley: University of California Press.

Papakostas, Apostolis. (2001). Why is there no Clientelism in Scandinavia? A Comparison of the Swedish and Greek Sequences of Development. In Piattoni (Ed.), Clientelism, Interests, and Democratic Representation: The European Experience in Historical and Comparative Perspective (pp. 31-53). Cambridge: Cambridge University Press.

Philp, Mark. (1997). Defining Political Corruption. Political Studies, 45(3), 436-462.

Peters, John G. and Susan Welch. (1978). Political Corruption in America: A Search for Definitions and a Theory, or If Political Corruption Is in the Mainstream of American Politics, Why Is it Not in the Mainstream of American Politics Research? American Political Science Review, 72(3), 974-984.

Piattoni, Simona. (2001). Clientelism in Historical and Comparative Perspective. In Piattoni (Ed.), Clientelism, Interests, and Democratic Representation: The European Experience in Historical and Comparative Perspective (pp. 1-30). Cambridge: Cambridge University Press.

Portes, Alejandro and William Haller. (2005). The Informal Economy. In Neil J. Smelser and Richard Swedberg (Eds), The Handbook of Economic Sociology (pp. 403-25). Princeton and New York: Princeton University Press / Russell Sage Foundation.

Randeraad, Nico and Dirk Jan Wolffram. (2001). Constraints on Clientelism: The Dutch Path to Modern Politics, 1848-1917. In Piattoni (Ed.), Clientelism, Interests, and Democratic Representation: The European Experience in Historical and Comparative Perspective (pp. 101-121). Cambridge: Cambridge University Press.

Remmer, Karen L. (2007). The Political Economy of Patronage: Expenditure Patterns in the Argentine Provinces, 1983-2003. The Journal of Politics, 69(2), 363-377.

Ricci, Paolo. (2003). O Conteúdo da Produção Legislativa Brasileira: Leis Nacionais ou Políticas Paroquiais? DADOS - Revista de Ciências Sociais, 46(4), 699-734.

Roniger, Luis. (1990). Hierarchy and Trust in Modern Mexico and Brazil. New York: Praeger.

Sandbrook, Richard. (1985). The Politics of Africa's Economic Stagnation. Cambridge: Cambridge University Press.

Saller, Richard P. (1982). Personal Patronage under the Early Empire. Cambridge: Cambridge University Press.

Sartori, Giovanni. (1970). Concept Misformation in Comparative Politics. American Political Science Review, LXIV(4), 1033-53.

Schaffer, Frederic C. (2007). Why Study Vote Buying? In Schaffer (Ed.), Elections for Sale: The Causes and Consequences of Vote Buying (pp. 1-16). Boulder: Lynne Rienner.

Schaffer, Frederic C. (2004). Vote buying in East Asia. In Global Corruption Report 2004 (pp. 83-87). Transparency International.

Schein, Edgar H. (2004). Organizational Culture and Leadership. $3^{\text {rd }}$ ed. San Francisco: Jossey-Bass, John Wiley and Sons.

Scheiner, Ethan. (2007). Clientelism in Japan: the importance and limits of institutional explanations. In Herbert Kitschelt and Steven J. Wilkinson (Eds.), Patrons, Clients, and Policies: Patterns of Democratic Accountability and Political Competition (pp. 276297). New York: Cambridge University Press.

Scott, James C. (1977). Patron-Client Politics and Political Change in Southeast Asia. In Schmidt, Guasti, Landé, and Scott (Eds), Friends, Followers, and Factions: A Reader in Political Clientelism (pp. 123-146). Berkeley: University of California Press. 
Scott, James C. (1985). Weapons of the Weak: Everyday Forms of Peasant Resistance. New Haven: Yale University Press.

Shinoda, Toru. (1997). Rengo and policy participation: Japanese style Neo-corporatism? In Mari Sako and Hiroki Sato (Eds), Japanese Labor and Management in Transition: diversity, flexibility and participation (pp. 187-214). London: Routledge.

Singelmann, Peter. (1981). Structures of Domination and Peasant Movements in Latin America. Columbia: University of Missouri Press.

Smelser, Neil J. (1997). Problematics of Sociology: The Georg Simmel Lectures, 1995. Berkeley: University of California Press.

Stokes, Susan. (2005). Perverse Accountability: A Formal Model of Machine Politics with Evidence from Argentina. American Political Science Review, 99(3), 315-325.

Stokes, Susan. (2007). Political Clientelism. In Stokes and Charles Boix (Eds), The Oxford Handbook of Comparative Politics (pp. 604-627). New York: Oxford University Press.

Wang, Chin-Shou, and Charles Kurzman. (2007). Dilemmas of Electoral Clientelism: Taiwan 1993. International Political Science Review, 28(2), 225-245.

Wantchekon, Leonard. (2003). Clientelism and Voting Behavior: Evidence from a Field Experiment in Benin. World Politics, 55(April), 399-422.

Weber, Max. (1978). Economy and Society: An Outline of Interpretive Sociology. Berkeley and Los Angeles: University of California Press.

Weingrod, Alex. (1977). Patrons, Patronage, and Political Parties. In Schmidt, Guasti, Landé, and Scott (Eds), Friends, Followers, and Factions: A Reader in Political Clientelism (pp.323-336). Berkeley: University of California Press.

\section{Intellectual Biography}

Tina Hilgers is Assistant Professor (LTA) at Concordia University in Montreal, Canada. She is the author of "La relation complexe entre clientélisme et démocratie (cadre de référence fondé sur le cas du PRD dans la ville de Mexico)" (2011), "Who is Using Whom? Clientelism from the Client's Perspective" (2009), "Causes and Consequences of Political Clientelism: Mexico's PRD in Comparative Perspective" (2008), and "Recentering Informality on the Research Agenda: Grassroots Action, Political Parties and Democratic Governance" (2008). She is currently working on a monograph about the changing dynamics of clientelism in Mexico and the PRD and an edited volume about the links between clientelism and democracy in Latin America. 